\title{
Embriogenesis dan Desikasi Embrio Somatik Jeruk Keprok Batu 55 (Citrus reticulata Blanco.) untuk Meningkatkan Frekuensi Perkecambahan
}

\author{
Embryogenesis and Desiccation of Tangerine var. Batu 55 (Citrus reticulata Blanco.) \\ Somatic Embryo on Enhancing Germination Frequency
}

Atika Fathur Rahmi $^{1^{*}}$, Agus Purwito ${ }^{2}$, Ali Husni ${ }^{3}$, dan Diny Dinarti ${ }^{2}$

Diterima 23 November 2016/Disetujui 10 Juli 2017

\begin{abstract}
In vitro breeding technique of citrus is effective when optimum explant regeneration method is obtained. Low germination frequency and high abnormality were barrier in citrus somatic embryogenesis. This research aimed at optimizing somatic embryogenesis in Tangerine var. Batu 55. This research consisted of 3 experiments. First experiment was maturation of embryogenesis, using Completely Randomized Design (CRD) method. Modified $M S+M W$ was used as basic media added with $500 \mathrm{mg} \mathrm{L}^{-1}$ malt extract (control) and addition of $3 \mathrm{mg} \mathrm{L}^{-1} B A P$, and $2.5 \mathrm{mg} \mathrm{L}^{-1} \mathrm{ABA}$ as treatments. Second experiment was SE (cotyledonary phage) desiccation. Factorial CRD used in two factors. First factor was poly-ethylene-glicol/PEG 8000 (0, 2.5, 5, 7.5 and 10\%), while second factor was immersed periods (control, 3, 6, and 9 hours), in desiccant solution (base medium + PEG). Third experiment was studied of plantlet growth and development planlets. Based on CRD 2 factor method, the first factor was PEG concentrations from the second experiment. Second factor were active charcoal treatments (with or without), in basic media. The result showed that $2.5 \mathrm{mg} \mathrm{L}^{-1} A B A$ produced has highest mature somatic embryo (SE). Desiccation for 9 hours, induced the highestt germination frequencies (90.29\%). The best growth of plantlets shown in previous experiments immersed desiccant PEG 2.5\% for 9 hours, and cultured in basic media with $2 \mathrm{~g} \mathrm{~L}^{-1}$ of activated charcoal.
\end{abstract}

Keywords: desiccant, embryogenic callus, maturation, PEG 8000, somatic embryo

\section{ABSTRAK}

Pemuliaan tanaman melalui teknik in vitro efektif bila metode regenerasi eksplan optimum telah diperoleh. Rendahnya frekuensi perkecambahan dan tingginya abnormalitas, menjadi kendala pada embriogenesis somatik jeruk. Penelitian terdiri atas 3 percobaan paralel, bertujuan mengoptimalkan metode embriogenesis somatik jeruk, khususnya Keprok Batu 55. Percobaan pertama pematangan kalus embriogenik menggunakan Rancangan Acak Lengkap (RAL) satu faktor, dengan perlakuan penambahan ZPT (kontrol, $3 \mathrm{mg} \mathrm{L}^{-1} \mathrm{BAP}$, dan $2.5 \mathrm{mg} \mathrm{L}^{-1} \mathrm{ABA}$ ) pada media dasar (MS modifikasi vitamin MW) diperkaya $500 \mathrm{mg} \mathrm{L}^{-1}$ ekstrak malt. Percobaan kedua desikasi embrio somatik (fase kotiledon) menggunakan RAL dua faktor. Faktor pertama konsentrasi poly-ethyleneglicol/PEG 8000 (0, 2.5, 5, 7.5 dan 10\%), dan faktor kedua waktu perendaman (kontrol, 3, 6, dan 9 jam) pada larutan desikan (media dasar + PEG). Percobaan ketiga mempelajari pertumbuhan dan perkembangan planlet, menggunakan RAL dua faktor. Faktor pertama konsentrasi PEG planlet pada percobaan kedua, dan faktor kedua perbedaan media dasar (tanpa dan dengan arang aktif). Hasil percobaan menunjukkan penambahan $2.5 \mathrm{mg} \mathrm{L}^{-1} \mathrm{ABA}$ menghasilkan maturasi embrio somatik terbaik. Desikasi 9 jam menghasilkan frekuensi perkecambahan $90.29 \%$. Pertumbuhan terbaik ditunjukkan planlet yang pada percobaan sebelumnya direndam 9 jam desikan PEG 2.5\%, dan dibesarkan pada media dasar dengan $2 \mathrm{~g} \mathrm{~L}^{-1}$ arang aktif.

Kata kunci : desikan, embrio somatik, kalus embriogenik, PEG 8000, pematangan

\footnotetext{
${ }^{1)}$ Program Studi Pemuliaan dan Bioteknologi Tanaman, Sekolah Pascasarjana, Institut Pertanian Bogor

${ }^{2)}$ Departemen Agronomi dan Hortikultura, Institut Pertanian Bogor

Jl. Meranti, Kampus IPB Darmaga, Bogor 16680, Indonesia

${ }^{3)}$ Balai Besar Bioteknologi dan Sumberdaya Genetik, Badan Penelitian dan Pengembangan Pertanian, Kementerian Pertanian,

J1. Tentara Pelajar No.3A Bogor Barat, Jawa Barat 16111, Indonesia

email: atikafathurrahmi@ymail.com (*penulis korespondensi)
} 


\section{PENDAHULUAN}

Jeruk Keprok Batu 55 (Citrus reticulata Blanco.) merupakan salah satu jeruk lokal unggulan nasional, berdasarkan Surat Keputusan Menteri Pertanian Nomor: 307/Kpts/SR.120/4/2006. Jeruk Keprok Batu 55 memiliki keunggulan dapat beradaptasi dengan baik di dataran tinggi, memiliki buah cukup besar berbentuk bulat, kulit buah matang dapat mencapai kuning sempurna, dan daging buah berwarna jingga (Balitbangtan, 2006). Namun, buah jeruk Keprok Batu 55 mempunyai banyak biji (rata-rata 12 biji per buah), dan rentan serangan beberapa hama penyakit. Peningkatan produksi serta kulitas jeruk agar memenuhi selera konsumen dan mampu bersaing di pasar global dapat diusahakan melalui pemuliaan in vitro. Keberhasilan peningkatan mutu dan kualitas jeruk secara in vitro sangat tergantung pada penguasaan sistem regenerasi, khususnya jalur embriogenesis somatik.

Embriogenesis somatik jeruk telah banyak dilakukan, namun masih terdapat beberapa permasalahan diantaranya persentase perkecambahan yang rendah dan tingginya abnormalitas. Beberapa peneliti melaporkan rendahnya frekuensi perkecambahan pada embriogenesis jeruk in vitro, diantaranya Husni et al. (2010) pada Siam Pontianak dan Simadu (58\%), Merigo (2011) pada Keprok Batu 55 (84\%), Kosmiatin et al. (2014) pada Siam Simadu (14.1\%), dan Karyanti et al. (2015) pada kalus Keprok Garut hasil iradiasi sinar gamma $(31.76 \%)$.

Perbaikan metode regenerasi jeruk secara in vitro dapat dilakukan dengan menambahkan tahapan desikasi pada proses embriogenesis somatik. Sesuai pernyataan West dan Harada (1993) embriogenesis merupakan proses regenerasi tanaman melalui beberapa tahapan yang dimulai dengan terbentuknya masa pro embriogenik (PEM), diikuti pembentukan embrio, maturasi (pematangan), desikasi (pengeringan) dan proses pertumbuhan tanaman regeneran. Embriogenesis tanaman (jeruk) in vitro umumnya tanpa melalui tahapan desikasi. Sebagaimana pernyataan George et al. (2008) embriogenesis tanaman in vitro umumnya melalui tahapan; inisiasi kultur embriogenik, proliferasi kalus embriogenik, pre-maturasi dan maturasi ES serta pembesaran tanaman regeneran.

Proses desikasi secara in vitro dapat dilakukan dengan teknik Sistem Perendaman Sesaat (SPS) atau Temporary Immersion System (TIS) (Riyadi dan Sumaryono, 2009), dengan meningkatkan pemberian sukrosa (Rai et al., 2008), meningkatkan konsentrasi bahan pemadat medium (Marquez-Martin et al., 2011; Hidayahti et al., 2013) atau menambahkan osmotikum seperti polyethylene-glycol (PEG) (Hidayahti et al., 2013). Sebagai osmotikum PEG dapat larut secara sempurna dan menurunkan potensial air secara homogen. Bartels dan Sunkar (2005) menyatakan PEG tidak mempunyai efek toksik pada tanaman, tetapi menurunkan potensial air media sehingga eksplan yang dikulturkan tidak mampu menyerap air dan nutrisi dari media. Pada penelitian ini dilakukan perendaman embrio somatik menggunakan PEG 8000 untuk meningkatkan frekuensi perkecambahan.

\section{BAHAN DAN METODE}

Penelitian ini telah dilaksanakan dari bulan Agustus 2014 sampai Mei 2015 di Laboratorium Kultur Jaringan I Departemen Agronomi dan Hortikultura, Institut Pertanian Bogor. Bahan yang digunakan adalah media MS (Murashige dan Skoog) modifikasi vitamin MW (Morel dan Wetmore) sebagai media dasar, ekstrak malt (EM), poly-ethyleneglycol (PEG) 8000, arang aktif, gula, agar-agar dan zat pengatur tumbuh (ZPT): benzil amino purin (BAP), abcisic acid (ABA), giberelin $\left(\mathrm{GA}_{3}\right)$. Penelitian terdiri atas tiga tahap percobaan: 1) induksi maturasi ES jeruk Keprok Batu 55; 2) desikasi dan germinasi ES jeruk Keprok Batu 55; dan 3) pertumbuhan dan perkembangan planlet hasil embriogenesis jeruk Keprok Batu 55.

\section{Induksi Maturasi Embrio Somatik Jeruk Keprok Batu 55}

Bahan yang digunakan adalah kalus embriogenik jeruk Keprok Batu 55 (berumur \pm 4 tahun sejak inisiasi). Rancangan percobaan yang digunakan adalah Rancangan Acak Lengkap (RAL) faktor tunggal. Media dasar ditambah $500 \mathrm{mg} \mathrm{L}^{-1} \mathrm{EM}$ dengan 1) $3 \mathrm{mg} \mathrm{L}^{-1}$ BAP, 2) $2.5 \mathrm{mg} \mathrm{L}^{-1} \mathrm{ABA}$ dan 3) kontrol tanpa 
penambahan ZPT, sebagai faktor perlakuan. Setiap perlakuan diulang 11 kali. Setiap ulangan terdiri atas 5 clump kalus embriogenik berdiameter $\pm 0.75 \mathrm{~cm}$ (berkisar \pm 35 PEM) . Karyanti et al. (2015) melaporkan setiap clump kalus jeruk Keprok Garut berdiameter sekitar $0.5 \mathrm{~cm}$ terdiri atas \pm 20 proembrio, sehingga kalus dengan diameter $\pm 0.75 \mathrm{~cm}$ diduga memiliki sekitar 35 embrio. Peubah yang diamati: ES yang terbentuk (fase globular, jantung, torpedo, dan kotiledon). Minggu keenam dilakukan penghitungan efisiensi pembentukan ES dengan menghitung jumlah tahap (globular + jantung + torpedo + kotiledon) dibagi jumlah PEM awal dan dikali $100 \%$.

Kalus embriogenik dengan ES yang belum dewasa (belum mencapai fase kotiledon) disubkultur pada media maturasi terbaik di 6 minggu pertama. Subkultur dilakukan secara berulang setiap 4 minggu, hingga memenuhi kebutuhan eksplan (embrio fase kotiledon) untuk desikasi pada percobaan berikutnya. Setiap kali subkultur, dilakukan penghitungan embrio fase kotiledon yang terbentuk.

\section{Desikasi dan Germinasi Embrio Somatik Jeruk Keprok Batu 55}

Bahan yang digunakan adalah ES jeruk Keprok Batu 55 fase kotiledon (dari perlakuan induksi maturasi). Rancangan percobaan yang digunakan adalah RAL dua faktor. Faktor pertama larutan media dasar (MS modifikasi vitamin MW) dengan PEG 8000 (konsentrasi: $0,2.5,5,7.5$ dan 10\%), sebagai desikan. Faktor kedua merupakan waktu perendaman (3, 6 dan 9 jam). Kombinasi ke dua faktor menghasilkan 15 perlakuan, dilengkapi satu kontrol tanpa perendaman sehingga menjadi 16 perlakuan. Setelah desikasi, ES dikecambahkan pada media dasar dengan 500 $\mathrm{mg} \mathrm{L}^{-1} \mathrm{EM}$ dan $2.5 \mathrm{mg} \mathrm{L}^{-1} \mathrm{GA}_{3}$ (Merigo, 2011). Setiap perlakuan terdiri atas 7 ulangan, sehingga terdapat 112 satuan percobaan. Setiap satu satuan percobaan terdiri atas 5 ES fase kotiledon. Lima minggu setelah tanam (MST) dilakukan penghitungan: jumlah eksplan berkecambah, eksplan membentuk kecambah normal, dan berkalus.

\section{Pertumbuhan dan Perkembangan Planlet Jeruk Keprok Batu 55}

Kecambah ES terbaik dari percobaan 2 Desikasi dan Germinasi Embrio, disubkultur ke media pembesaran. Rancangan percobaan yang digunakan adalah RAL dua faktor. Faktor pertama terdiri atas 6 perlakuan ES sebelumya (PEG konsentrasi 0, 2.5, 5, 7.5 dan 10\%, serta dilengkapi satu kontrol tanpa perendaman). Faktor kedua media dasar, tanpa dan dengan arang aktif $2 \mathrm{~g} \mathrm{~L}^{-1}$. Terdapat 12 kombinasi perlakuan, yang terdiri atas 4 ulangan, sehingga terdapat 48 satuan percobaan. Setiap satuan percobaan terdiri atas 3 planlet. Pada minggu keenam dilakukan penghitungan: persentase eksplan hidup, membentuk planlet normal, membentuk tunas, membentuk daun, membentuk akar dan membentuk ES sekunder serta jumlah tunas, daun, akar, dan tinggi pada setiap eksplan.

Data yang diperoleh pada setiap percobaan dianalisis menggunakan program Statistical Tool for Agricultural Reasearch (STAR-2.0.1). Perlakuan yang menunjukkan pengaruh berdasarkan hasil uji $\mathrm{F}$, diuji lanjut menggunakan uji beda nyata terkecil (BNT) atau least significant differences (LSD) pada taraf 5\% $(\mathrm{P}<0.05)$.

\section{HASIL PEMBAHASAN}

\section{Induksi Maturasi Embrio Somatik Jeruk Keprok Batu 55}

Formulasi media sangat menentukan keberhasilan induksi dan maturasi ES. Interaksi dan perimbangan ZPT yang ditambahkan ke dalam media dan hormon yang diproduksi secara endogen menentukan arah perkembangan suatu kultur. Minggu pertama dan ke dua semua kalus masih menunjukkan warna putih kekuningan. Perubahan warna mulai terjadi pada minggu ke tiga setelah sub kultur (Gambar 1). Kaluskalus yang berpotensi membentuk embrio mulai menunjukkan warna kuning kehijauan seiring dengan mulai berkembangnya proembrio menjadi embrio. Penghitungan ES pada minggu ke enam menunjukkan fase globular lebih banyak ditemukan dibandingkan jantung, torpedo dan kotiledon. Souza et al. (2011) menyatakan embrio tahap globular lebih mudah dideteksi pada Citrus sinensis L. Obseck cv. Valencia. 

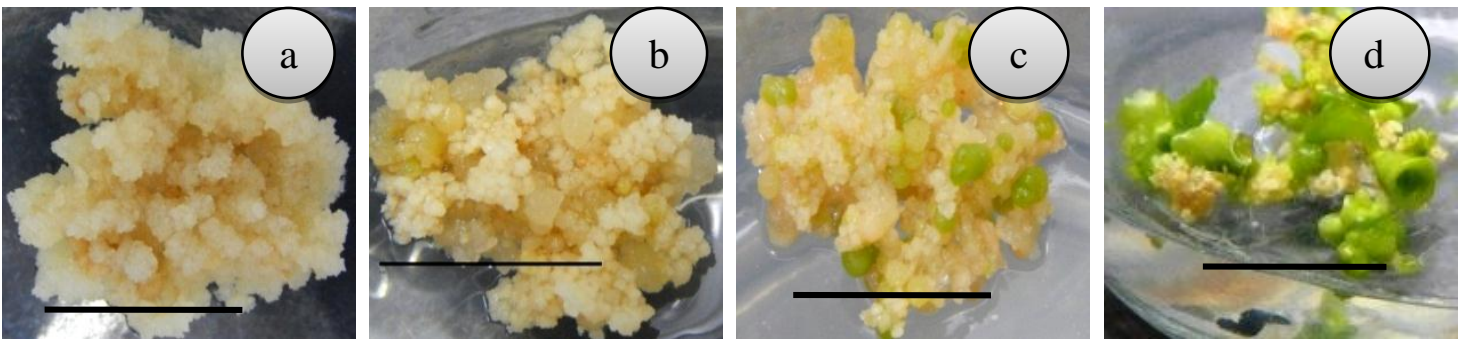

Gambar 1. Induksi maturasi kalus embriogenik jeruk Keprok Batu 55 a) 2 MST b) 3 MST c) 4 MST d) 6 MST pada media dasar $+500 \mathrm{mgL}^{-1} \mathrm{EM}+2.5 \mathrm{mgL}^{-1} \mathrm{ABA}$, bar $=1 \mathrm{~cm}$.

Beberapa proembrio dapat berkembang menjadi embrio tanpa penambahan ZPT (Tabel 1). Kandungan hormon pada jaringan proembrio yang dimaturasi di media tanpa penambahan ZPT diduga telah dapat mendukung perkembangannya menjadi ES. Menurut Husni et al. (2010) embriogenesis somatik dapat terjadi secara langsung dari selsel meristemoid dan embrioid yang tumbuh dan berkembang menjadi ES dengan dua kutub (bipolar). Penambahan $3 \quad \mathrm{mg} \quad \mathrm{L}^{-1} \quad$ BAP menginduksi maturasi lebih baik dibandingkan kontrol. Secara umum, populasi kalus pada media dengan $3 \quad \mathrm{mg} \mathrm{L}^{-1}$ BAP kembali berproliferasi. Kandungan sitokinin yang tinggi menginduksi populasi kalus untuk cenderung berproliferasi menjadi kalus baru. Tabel 1 menunjukkan penambahan $2.5 \mathrm{mg} \mathrm{L}^{-1} \mathrm{ABA}$ menghasilkan (maturasi) ES paling baik (34.89\%). Sesuai penelitian George et al. (2008) dengan eksplan daun jeruk, Husni et al. (2010) pada Siam Pontianak dan Simadu, Merigo (2011) pada Keprok Batu 55, Wulansari et al. (2015) pada regenerasi kalus Siam, Karyanti et al. (2015) pada Keprok Garut, Purwito et al. (2015) Keprok Batu 55, bahwa ABA meningkatkan diferensiasi ES menjadi embrio dewasa. Abcisic acid termasuk kelompok ZPT yang berperan sebagai inhibitor, berperan dalam peningkatan embriogenesis, ketahanan terhadap stres, dormansi, perkecambahan dan pertumbuhan (Harjadi, 2009).

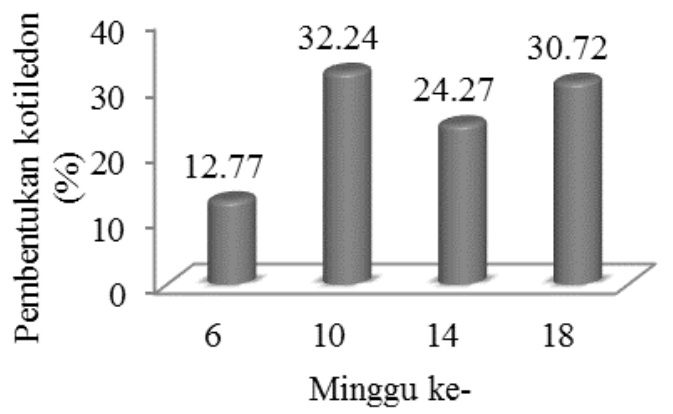

Gambar 2. Persentase embrio dewasa (fase kotiledon) yang terbentuk setiap kali subkultur, pada media dengan penambahan ABA $2.5 \mathrm{mg} \mathrm{L}^{-1}$

Tabel 1. Pematangan ES jeruk Keprok Batu 55, pada 6 MST di media induksi maturasi

\begin{tabular}{lcrrrrr}
\hline \multirow{2}{*}{$\begin{array}{c}\text { MS modifikasi } \\
\text { Vitamin MW }\end{array}$} & $\begin{array}{c}\text { Jumlah } \\
\text { PEM* }\end{array}$ & \multicolumn{3}{c}{ Tahapan Pendewasaan Embrio Somatik } & $\begin{array}{c}\text { Efisiensi } \\
\text { Pendewasaan } \\
(\%)\end{array}$ \\
\hline Kontrol & 35 & $0.84 \mathrm{c}$ & $0.00 \mathrm{~b}$ & $0.00 \mathrm{~b}$ & $0.00 \mathrm{~b}$ & 2.4 \\
$3 \mathrm{mg} \mathrm{L}^{-1} \mathrm{BAP}$ & 35 & $2.48 \mathrm{~b}$ & $0.06 \mathrm{~b}$ & $0.00 \mathrm{~b}$ & $0.00 \mathrm{~b}$ & 7.3 \\
$2.5 \mathrm{mg} \mathrm{L}^{-1} \mathrm{ABA}$ & 35 & $10.24 \mathrm{a}$ & $1.31 \mathrm{a}$ & $0.36 \mathrm{a}$ & $0.30 \mathrm{a}$ & 34.9 \\
\hline KK $(\%)$ & & 2.4 & 18.7 & 11.0 & 9.5 & \\
\hline
\end{tabular}

Keterangan: Angka-angka yang diikuti huruf yang sama pada kolom yang sama menunjukkan tidak berbeda nyata ( $\alpha$ $=0.05)$ pada uji LSD. KK merupakan hasil transformasi menggunakan $\sqrt{ }(x+1)$. *Perkiraan jumlah proembrio per clump dengan diameter kalus $\pm 0.75 \mathrm{~cm}$. 
Kalus embriogenik dengan ES yang belum dewasa (belum mencapai fase kotiledon) selanjutnya disubkultur ke media dengan ABA $2.5 \mathrm{mg} \mathrm{L}^{-1}$, dengan subkultur setiap 4 minggu sekali. Pembentukan embrio dewasa fase kotiledon tertinggi (Gambar 2) diperoleh pada minggu ke-10, mencapai $32.24 \%$ (255 kotiledon). Hal tersebut menunjukkan, bahwa selain ditentukan oleh kemampuan sel menerima rangsangan dari media dengan ABA, proses pematangan ES juga ditentukan oleh umur fisiologis sel embrio somatik.

\section{Desikasi dan Germinasi Embrio Somatik Jeruk Keprok Batu 55}

Perkecambahan terlihat optimal pada minggu ke enam, meskipun tidak semua ES berkecambah dan berkembang menjadi kecambah normal. Tidak terdapat interaksi antara waktu perendaman dan konsentrasi PEG desikan. Perbedaan konsentrasi PEG pada larutan desikan juga tidak berpengaruh nyata. Lama (waktu) perendaman ES fase kotiledon pada larutan desikan (sebelum pengecambahan), berpengaruh terhadap ratarata eksplan yang dapat berkecambah dan membentuk kecambah normal.

Tabel 2 menunjukkan ES jeruk Keprok Batu 55 dapat berkecambah tanpa proses desikasi, terlihat dari hasil perkecambahan kontrol tanpa perendaman (68.57\%). Embrio yang matang sempurna dapat berkecambah alami pada media yang optimal. Rendahnya embrio berkecambah (2.40 ES) dan berkecambah normal (0.09 ES) pada desikasi tiga jam, diduga karena shock effect yang dialami embrio akibat tercekam. Konservasi air antar sel pada jaringan embrio diduga belum optimal pada desikasi singkat. Masih kurang beradaptasinya embrio terhadap larutan desikan pada tiga jam pertama, menyebabkan perkecambahan yang lebih rendah dari kontrol, mengindikasikan prelakuan desikasi selama tiga jam belum optimal.

Proses desikasi ES meningkatkan frekuensi perkecambahan pada perendaman selama enam jam (89.72\%) dan sembilan jam (90.29\%). Perendaman ES jeruk Keprok Batu 55 selama sembilan jam dalam larutan desikan menunjukkan hasil terbaik, dengan rata-rata 4.51 ES berkecambah dan 2.80 diantaranya (dari 4.51 kecambah) berkecambah normal. Penggunaan desikan pada konsentrasi rendah dan waktu relatif lama, menarik air yang tersimpan pada lapisan jaringan sel bagian dalam ke lapisan luar secara bertahap, sebagai mekanisme pertahanan embrio terhadap cekaman kekeringan yang diterima oleh sel-sel yang berada pada permukaan. Sesuai pernyataan Jones (1992) bahwa peningkatan konservasi air pada jaringan merupakan salah satu mekanisme tanaman untuk menghindari defisit air. Hal ini menyebabkan embrioembrio yang lebih lama direndam larutan desikan lebih adaptif dan menghasilkan frekuensi perkecambahan yang lebih tinggi.

Tabel 2. Perkembangan ES fase kotiledon jeruk Keprok Batu 55, pada 6 MST di media dasar dengan $500 \mathrm{mg} \mathrm{L}^{-1} \mathrm{EM}$ dan $2.5 \mathrm{mg} \mathrm{L}^{-1} \mathrm{GA}_{3}$ (setelah perlakuan desikasi)

\begin{tabular}{|c|c|c|c|c|c|}
\hline \multirow[b]{2}{*}{ Perlakuan PEG } & \multicolumn{3}{|c|}{ Rataan Jumlah Embrio (kotiledon) } & \multirow{2}{*}{$\begin{array}{c}\text { Efisiensi } \\
\text { Perkecambahan } \\
(\%)\end{array}$} & \multirow{2}{*}{$\begin{array}{c}\text { Persentase } \\
\text { ES Berkalus } \\
(\%)\end{array}$} \\
\hline & $\begin{array}{c}\text { Awal } \\
\text { Tanam }\end{array}$ & Berkecambah & $\begin{array}{c}\text { Kecambah } \\
\text { Normal }\end{array}$ & & \\
\hline \multicolumn{6}{|l|}{ Waktu (jam) } \\
\hline Tanpa Perendaman & 5 & $3.4 \mathrm{~b}$ & $0.9 \mathrm{~b}$ & $68.6 \mathrm{~b}$ & $48.0 \mathrm{a}$ \\
\hline 3 & 5 & $2.4 \mathrm{c}$ & $0.1 \mathrm{c}$ & $48.0 \mathrm{c}$ & 57.9 a \\
\hline 6 & 5 & $4.5 \mathrm{a}$ & $1.3 \mathrm{~b}$ & $89.7 \mathrm{a}$ & $36.9 \mathrm{ab}$ \\
\hline 9 & 5 & $4.5 \mathrm{a}$ & $2.8 \mathrm{a}$ & $90.3 \mathrm{a}$ & $20.4 \mathrm{~b}$ \\
\hline \multicolumn{6}{|l|}{ Konsentrasi (\%) } \\
\hline 0 & 5 & 4.1 & 1.5 & 81.9 & 33.7 \\
\hline 2.5 & 5 & 3.6 & 1.4 & 72.4 & 42.7 \\
\hline 5.0 & 5 & 3.5 & 1.3 & 69.5 & 36.8 \\
\hline 7.5 & 5 & 4.1 & 1.3 & 82.9 & 34.4 \\
\hline 10.0 & 5 & 3.7 & 1.4 & 73.3 & 44.5 \\
\hline KK & & $6.58 \%$ & $11.41 \%$ & & \\
\hline
\end{tabular}

Keterangan: Angka-angka yang diikuti huruf yang sama pada kolom yang sama tidak berbeda nyata $(\alpha=0.05)$ pada uji LSD. KK merupakan hasil transformasi menggunakan $\sqrt{(x+1)}$. 
Selain fator kematangan, perkecambahan ES dipengaruhi kemampuan sel embrio somatik menerima rangsangan media dengan penambahan $\mathrm{GA}_{3}$. Husni et al. (2010) menyatakan semakin tinggi konsentrasi $\mathrm{GA}_{3}$, semakin banyak jumlah ES yang berkecambah menjadi planlet. Penambahan $4 \mathrm{ppm} \mathrm{GA}_{3}$ meningkatkan berat basah embrio sedangkan aplikasi 8 ppm $\mathrm{GA}_{3}$ pada tahap multiplikasi menghasilkan persentase regenerasi embrio paling tinggi (Firdiana et al., 2015). Perendaman eksplan selama 3 jam pada $10 \mathrm{mg}$ $\mathrm{L}^{-1} \mathrm{GA}_{3}$ meningkatkan perkecambahan dan pemanjangan tunas (Putra et al., 2015)

Terdapat pembentukan kalus disekitar meristem embrio yang berkecambah. Eksplan membentuk kalus tertinggi ditunjukkan perlakuan perendaman 3 jam yang tidak berbeda nyata dengan kontrol tanpa perendaman (Tabel 2). Kosmiatin et al. (2014) juga melaporkan terdapat pembentukan (88.9\%) kalus embriogenik pada pangkal eksplan jaringan endosperm jeruk Siam Simadu yang berkecambah. Terinduksinya kalus di sekitar meristem embrio yang berkecambah mengindikasikan media dasar yang digunakan sangat optimal untuk regenerasi ES jeruk, sehingga dapat merangsang jaringan meristemoid berproliferasi membentuk sel-sel baru (kalus).

Kalus disekitar eksplan yang sangat aktif berproliferasi terkadang justru menghambat perkembangan planlet dan diduga menyebabkan kematian pada beberapa eksplan. Kalus tersebut bersaing dengan eksplan dalam hal pemenuhan kebutuhannya di dalam botol kultur. Sejalan dengan penelitian Devy et al. (2012) bahwa densitas (kepadatan) kultur sangat berpengaruh terhadap daya regenerasi eksplan.

\section{Pertumbuhan dan Perkembangan Planlet Jeruk Keprok Batu 55}

Analisis ragam planlet hasil desikasi selama 9 jam pada 5 MST di media pembesaran (Tabel 3), menunjukkan media berpengaruh nyata terhadap tinggi planlet. Rata-rata tinggi planlet pada media dengan arang aktif $(0.99 \mathrm{~cm})$ mencapai hampir dua kali lipat tinggi planlet pada media tanpa arang aktif $(0.54 \mathrm{~cm})$. Mengindikasikan media MS modifikasi vitamin MW dengan penambahan arang aktif, lebih optimal dalam mendukung pertumbuhan tinggi planlet.

Konsentrasi PEG berpengaruh terhadap beberapa peubah yang diamati. Nilai terbaik berdasarkan persentase eksplan membentuk planlet normal (50\%), bertunas $(50 \%)$, berdaun $(41.67 \%)$, berakar $(70.83 \%)$, serta rata-rata jumlah tunas (1.92) per eksplan ditunjukkan oleh planlet yang pada percobaan sebelumnya direndam larutan desikan PEG $2.5 \%$ selama 9 jam (Tabel 3). Interaksi antar media pembesaran dengan konsentrasi PEG larutan desikan, terdapat pada parameter ratarata jumlah akar yang terbentuk pada setiap eksplan (Tabel 4) dan persentase planlet membentuk embrio somatik sekunder (Tabel 5).

Tabel 3. Perkembangan planlet jeruk Keprok Batu 55 (hasil desikasi 9 jam), pada 5 MST di media pembesaran

\begin{tabular}{|c|c|c|c|c|c|c|c|}
\hline \multirow[b]{2}{*}{$\begin{array}{l}\text { Perlakuan } \\
\text { (treatments) }\end{array}$} & \multicolumn{4}{|c|}{ Persentase Eksplan } & \multicolumn{3}{|c|}{ Rata-rata (per eksplan) } \\
\hline & $\begin{array}{c}\text { Normal } \\
(\%)\end{array}$ & $\begin{array}{c}\text { Bertunas } \\
(\%)\end{array}$ & $\begin{array}{c}\text { Berdaun } \\
(\%)\end{array}$ & $\begin{array}{c}\text { Berakar } \\
(\%)\end{array}$ & Tunas & Daun & $\begin{array}{l}\text { Tinggi } \\
(\mathrm{cm})\end{array}$ \\
\hline Media & & & & & & & \\
\hline MS + vit MW & 26.4 & 27.8 & 25.0 & 43.1 & 1.4 & 2.5 & $0.5 \mathrm{~b}$ \\
\hline MS+vit MW+aa & 30.6 & 37.5 & 30.6 & 51.4 & 1.1 & 3.1 & $1.0 \mathrm{a}$ \\
\hline \multicolumn{8}{|c|}{ Konsentrasi PEG $(\%)$} \\
\hline Kontrol & $4.2 \mathrm{c}$ & $8.3 \mathrm{~b}$ & $0.0 \mathrm{c}$ & $4.2 \mathrm{~b}$ & $0.3 \mathrm{~b}$ & $0.0 \mathrm{c}$ & 0.2 \\
\hline 0 & $37.5 \mathrm{ab}$ & $37.5 \mathrm{a}$ & $41.7 \mathrm{ab}$ & $54.2 \mathrm{a}$ & $1.3 \mathrm{a}$ & $5.8 \mathrm{a}$ & 1.0 \\
\hline 2.5 & $50.0 \mathrm{a}$ & $50.0 \mathrm{a}$ & $41.7 \mathrm{a}$ & $70.8 \mathrm{a}$ & $1.9 \mathrm{a}$ & $4.8 \mathrm{a}$ & 1.2 \\
\hline 5.0 & $25.0 \mathrm{ab}$ & $37.5 \mathrm{a}$ & $29.2 \mathrm{ab}$ & $58.3 \mathrm{a}$ & $1.1 \mathrm{ab}$ & $1.4 \mathrm{bc}$ & 0.7 \\
\hline 7.5 & $20.8 \mathrm{~b}$ & $25.0 \mathrm{a}$ & $20.8 \mathrm{~b}$ & $45.8 \mathrm{a}$ & $1.4 \mathrm{a}$ & $1.8 \mathrm{bc}$ & 0.6 \\
\hline 10.0 & $33.3 \mathrm{ab}$ & $37.5 \mathrm{a}$ & $33.3 \mathrm{ab}$ & $50.0 \mathrm{a}$ & $1.7 \mathrm{a}$ & $2.9 \mathrm{ab}$ & 0.9 \\
\hline
\end{tabular}

Keterangan: Angka-angka yang diikuti huruf yang sama pada kolom yang sama, tidak berbeda nyata $(\alpha=0.05)$ pada uji LSD. KK merupakan hasil transformasi menggunakan $\log (x+1)$. 
Tabel 4. Pengaruh interaksi media dan konsentrasi PEG terhadap rata-rata jumlah akar per planlet jeruk Keprok Batu 55 setelah 5 minggu berada pada media pertumbuhan

\begin{tabular}{|c|c|c|}
\hline \multirow{2}{*}{ Konsentrasi PEG (\%) } & \multicolumn{2}{|c|}{ Media } \\
\hline & MS+vit MW & MS+vit MW + Arang Aktif \\
\hline Kontrol & $0.3 \mathrm{c} \quad \mathrm{A}$ & $0.0 \mathrm{~b} \quad \mathrm{~A}$ \\
\hline 0 & $1.6 \mathrm{~b} \quad \mathrm{~A}$ & $1.3 \mathrm{a} \quad \mathrm{A}$ \\
\hline 2.5 & 3.2 a A & $1.4 \mathrm{a} \quad \mathrm{B}$ \\
\hline 5.0 & $1.0 \mathrm{bc} \mathrm{A}$ & $1.9 \mathrm{a}$ \\
\hline 7.5 & $1.4 \mathrm{~b} \quad \mathrm{~A}$ & $1.0 \mathrm{a}$ \\
\hline 10.0 & $1.3 \mathrm{~b} \quad \mathrm{~A}$ & $1.3 \mathrm{a} \quad \mathrm{A}$ \\
\hline
\end{tabular}

Keterangan: Angka-angka pada kolom yang sama yang diikuti oleh huruf kecil yang sama tidak berbeda nyata $(\alpha=$ $0.05)$, sedangkan angka-angka pada baris yang sama yang diikuti oleh huruf kapital yang sama tidak berbeda nyata $(\alpha=0.05)$ pada uji LSD.

Tabel 5. Pengaruh interaksi media dan konsentrasi PEG terhadap persentase planlet jeruk Keprok Batu 55 membentuk ES sekunder pada 5 MST di media pertumbuhan.

\begin{tabular}{|c|c|c|}
\hline \multirow{2}{*}{ Konsentrasi PEG (\%) } & \multicolumn{2}{|c|}{ Media } \\
\hline & MS + vit MW & MS + vit MW + Arang Aktif \\
\hline Kontrol & $25.0 \mathrm{ab} \quad \mathrm{B}$ & $75.0 \mathrm{a} \quad \mathrm{A}$ \\
\hline 0 & $50.0 \mathrm{ab}$ & $0.0 \mathrm{~b}$ \\
\hline 2.5 & $33.3 \mathrm{ab}$ & $16.7 \mathrm{~b} \quad \mathrm{~A}$ \\
\hline 5.0 & $25.0 \mathrm{ab}$ & $16.7 \mathrm{~b} \quad \mathrm{~A}$ \\
\hline 7.5 & $58.3 \mathrm{a}$ & $0.0 \mathrm{~b} \quad \mathrm{~B}$ \\
\hline 10.0 & $8.3 \mathrm{~b}$ & $16.7 \mathrm{~b} \quad \mathrm{~A}$ \\
\hline
\end{tabular}

Keterangan: Angka-angka pada kolom yang sama yang diikuti oleh huruf kecil yang sama tidak berbeda nyata $(\alpha=$ 0.05 ), sedangkan angka-angka pada baris yang sama yang diikuti oleh huruf kapital yang sama tidak berbeda nyata $(\alpha=0.05)$ pada uji LSD.

Pada media tanpa arang aktif, rata-rata jumlah akar terbanyak terdapat pada konsentrasi PEG 2.5\% (3.17 akar per eksplan), sedangkan pada media dengan arang aktif terdapat pada eksplan yang sebelumnya direndam larutan desikan PEG dengan konsentrasi $5 \%$, yaitu 1.92 akar per eksplan (Tabel 4). Pada parameter persentase planlet membentuk embrio somatik sekunder (Tabel 5), persentase eksplan membentuk ES sekunder di media tanpa arang aktif (Gambar 3d) tertinggi ditunujukkan eksplan yang sebelumnya direndam desikan $7.5 \%$ PEG (58.33\%), sedangkan pada media dengan penambahan arang aktif terdapat pada kontrol tanpa perendaman (75\%). Kosmiatin et al. (2014) melaporkan $44.4 \%$ planlet membentuk ES sekunder di sekitar pangkal batang, pada tahap pemanjangan tunas kultur endosperm Siam Simadu.

Pada percobaan ini terlihat keragaman morfologi planlet seperti abnormal, tunas, batang dan atau daun tidak dapat dibedakan dengan jelas, keriting, menebal, roset, dan tidak berkembang dengan baik. Penyimpangan yang terjadi tidak selalu dapat dikategorikan sebagai abnormalitas, karena beberapa tanaman yang dihasilkan masih memenuhi kriteria sebagai planlet yaitu memiliki batang, akar dan daun. Beberapa eksplan yang abnormal juga dapat tumbuh dan berkembang menjadi planlet normal setelah subkultur berulang, seiring dengan semakin dewasanya planlet (Gambar $3 \mathrm{abc}$ ).

Proses embriogenesis pada beberapa eksplan juga terlihat menyimpang, karena embriogenesis pada tanaman dikotil seharusnya menghasilkan planlet berakar tunggang dengan tunas tunggal. Rata-rata planlet pada penelitian ini menghasilkan tunas (Tabel 3) dan akar (Tabel 4) lebih dari satu, pada satu eksplan. Beberapa penyimpangan yang terjadi diduga karena terdapat kelebihan cadangan protein pada eksplan. Penggunaan media dasar MS modifikasi vitamin MW merupakan media yang kaya nutrisi. Vitamin MW mengandung biotin dan Ca-pantotenat yang tidak terdapat pada vitamin MS. 

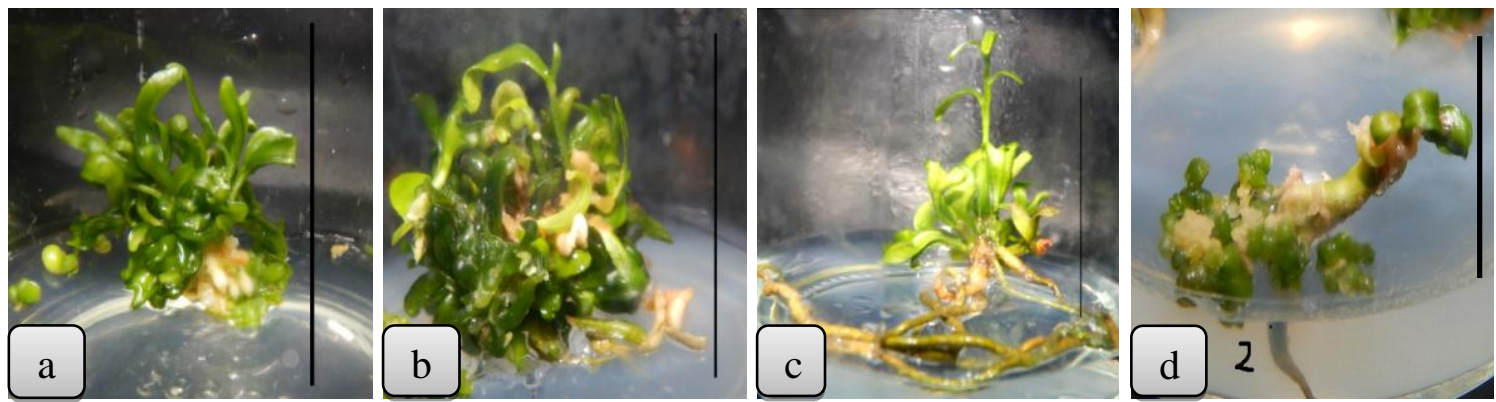

Gambar 3. Perkembangan planlet jeruk Keprok Batu 55 abnormal menjadi planlet normal pada media MS modifikasi vitamin MW a) 3 MST b) 6 MST c) 12 MST d) ES sekunder terbentuk pada pangkal batang, bar $=3 \mathrm{~cm}$.

Ca-pantotenat berperan sebagai penyumbang kalsium dan asam pantotenat yang berfungsi mencegah penuaan pada jaringan. Biotin dapat mempengaruhi perkembangan kalus embriogenik. Aktivitas biotin yang bersifat sebagai kofaktor sintesis protein cadangan, menyebabkan terjadinya akumulasi cadangan protein (Dodeman et al., 1997). Selama pertumbuhan (sejak kalus hingga berkecambah) media yang digunakan diperkaya ekstrak malt, sehingga terdapat ketersediaan nitrogen organik yang mudah diserap tanaman. Tingginya akumulasi protein cadangan pada eksplan diduga menyebabkan terjadinya abnormalitas dan terbentuknya embrio somatik sekunder. Kosmiatin et al. (2014) menyatakan penumpukan protein cadangan menyebabkan terbentuknya embrio somatik sekunder dan terjadinya abnormalitas pada embriogenesis somatik.

Faktor kalus sebagai eksplan awal yang telah berumur lebih dari 4 tahun (sejak inisiasi) dan mengalami sub kultur berulang kali juga diduga memunculkan pengaruh variasi somaklonal. Yulianti et al. (2012) melaporkan penggunaan ZPT BAP yang cukup tinggi dan periode kultur yang lama pada perbanyakan melalui embriogenesis somatik, menyebabkan terjadinya perubahan genetik. Pengaruh dari lingkungan in vitro yang sangat berbeda dengan habitat asli tanaman di lapangan, kemungkinan juga memunculkan efek epigenetik.

\section{KESIMPULAN}

Penambahan $2.5 \mathrm{mg} \mathrm{L}^{-1}$ ABA pada media kultur meningkatkan jumlah embrio somatik dewasa dengan efisiensi keberhasilan mencapai $34.53 \%$. Desikasi embrio somatik dewasa (fase kotiledon) menggunakan larutan desikan PEG 8000 selama 9 jam berhasil meningkatkan frekuensi perkecambahan hingga $90.29 \%$. Pertumbuhan planlet hasil desikasi 9 jam paling baik berasal dari perlakuan menggunakan desikan 2.5\% PEG yang ditumbuhkan pada media dengan penambahan arang aktif $2 \mathrm{~g} \mathrm{~L}^{-1}$.

\section{DAFTAR PUSTAKA}

[Balitbangtan] Badan Penelitian dan Pengembangan Departemen Pertanian. 2006. Surat Keputusan Menteri Pertanian Nomor 307/Kpts/SR.1204/ 4/2006 tentang Pelepasan Jeruk Keprok Batu 55 sebagai varietas unggul. Jakarta: Balitbangtan Deptan.

Bartels, D., R. Sunkar. 2005. Drought and salt tolerance in plants. Crit. Rev. in Plant Sci. 24: 1-36.

Devy, N.F., F. Yulianti, Hardiyanto. 2012. Pengaruh densitas awal kalus dalam perbanyakan melalui embriogenesis somatik terhadap daya multiplikasi dan stabilitas genetik planlet siam Kintamani. J. Hort. 22(4): 309-315.

Dodeman, V.L., G. Ducreux, M. Kreis. 1997. Zygotic embryogenesis versus somatic embryogenesis. J. Exp. Bot. 48: 14931509.

Firdiana, E.F., S. Indriyani, W. Widoretno. 2015 The effect of gibbberellin on somatic embryo growth and maturtion 
and plantlet regeneration of tangerine (Citrus reticulata Blanco.) var.Batu 55. J. Exp.Life Sci. 5(1): 19-23.

George, E.F., M.A. Hall, G.J. De Klerk. 2008. Plant Propagation by Tissue Culture. Volume ke 1. The Background. Edisi ke-3. Netherland: Springer. hlm 335354.

Harjadi, S.S. 2009. Zat Pengatur Tumbuh. Jakarta. Penebar Swadaya.

Hidayahti, N., W. Widoretno, R. Mastuti. 2013. Pengaruh osmolit terhadap maturasi embrio somatik jeruk (C. reticulata Blanco.). El-Hayah. 3(2): 83-87.

Husni, A., A. Purwito, I. Mariska, Sudarsono. 2010. Regenerasi jeruk siam melalui embriogenesis somatik. J. AgroBiogen. 6(2): 75-83.

Jones HG. 1992. Plants and Microclimate. A Quantitative Approach to Environmental Plant Physiology. Second edition Cambridge University Press. p: 265-295.

Karyanti, A. Purwito, A. Husni. 2015. Radiosensitivitas dan seleksi mutan putatif jeruk keprok Garut (Citrus reticulata L.) berdasarkan penanda morfologi. J. Agron. Indonesia 43(2): 126-132.

Kosmiatin, M., A. Purwito, G.A. Wattimena, I. Mariska. 2014. Induksi embriogenesis somatik jaringan endosperm jeruk Siam Simadu. J. Agron. Indonesia. 42(1): 4451.

Marquez-Martin, B., R. Sesmeroa, M.A. Quesada, F. Pliego-Alfaroc, C. SanchezRomero. 2011. Water relations in culture media influence maturation of avocado somatic embryos. Plant Physiol. 168: 2028-2034.

Merigo, J.A. 2011. Studi regenerasi tanaman jeruk Keprok Batu 55 melalui jalur embrigenesis somatik. [Tesis]. Sekolah Pascasarjana. Institut Pertanian Bogor.
Purwito, A., M. Prayogi, M. Kosmiatin, A. Husni. 2015. Embriogenesis somatik jeruk Keprok (Citrus L. cv Batu 55) asal hasil perlakuan kolkisin. J. Hort. Indonesia. 6(3): 161-171.

Putra, I.M.A., A. Purwito, M. Kosmiatin. 2015 Propagasi mikro dan sambung mikro jeruk keprok (Citrus reticulata) Garut hasil mutagenesis in vitro dengan batang bawah Japansche Citroen. J. Hort. Indonesia. 8(2): 99-108.

Rai, M.K., V.S. Jaiswal, U. Jaiswal. 2008. Effect of ABA and sucrose on germination of encapsulated somatic embryos of guava (Psidium guajava $\mathrm{L}$.). Sci. Hort. 117: 302-305.

Riyadi, I., Sumaryono. 2009. Pengaruh interval dan lama perendaman terhadap pertumbuhan dan pendewasaan embrio somatik tanaman sagu (Metroxylon sagu Rottb.). J. Menara Perkebunan. 77(2): 101-110.

Souza, J.M.M., M.L .Tomaz, S.C.C. Arruda, C.G.B. Demetrio, W.N. Venables, A.P. Martinelli. 2011. Callus sieving is effective in improving synchronization and frequency of somatic embryogenesis in Citrus sinensis. Biologia Plantarum. 55(4): 703-707.

West, M.A.L., J.J. Harada. 1993. Embryogenesis in higher plants: An overview. J. Plant Cell. 5: 1361-1369.

Wulansari, A., A. Purwito, A. Husni, E. Sudarmonowati. 2015. Kemampuan regenerasi kalus embriogenik asal nuselus jeruk siam serta variasi fenotipe tunas regeneran. Prosiding Seminar Nasional Masyarakat Biodiversitas Indonesia. 1(1): 97-104.

Yulianti, F., N.F. Devy. F. Widyaningsih. 2012. Evaluasi variasi somaklonal pada benih jeruk hasil perbanyakan melalui embriogenesis somatik. J. Hort. 22(3): 210-216. 